\title{
Success Indicators of Mathematical Problem- Solving Performance Among Malaysian Matriculation Students
}

\author{
Suriati Abu Bakar, Nur Raidah Salim, \\ Ahmad Fauzi Mohd Ayub and Kathiresan Gopal \\ Institute for Mathematical Research, Universiti Putra Malaysia, Malaysia \\ https:// orcid.org/0000-0002-5572-9611 \\ https://orcid.org/0000-0002-7941-1878 \\ https://orcid.org/0000-0002-4313-2922 \\ https:// orcid.org/0000-0001-5302-8179
}

\begin{abstract}
This study identifies the success indicators of mathematical problem-solving performances among Malaysian matriculation students divided into four indicators: mathematical beliefs, mathematics attitudes, mathematics self-efficacy and metacognitive skills. For this purpose, 368 matriculation students from three matriculation colleges were selected as respondents using proportioned stratified sampling. This study utilized a descriptive correlational design approach. A set of questionnaires and a mathematics test were used as the instruments. Independent variables were measured using a questionnaire, while mathematical problemsolving performance was measured using a mathematics test. The findings show students had a high level in mathematics beliefs, attitude towards mathematics, mathematics self-efficacy and metacognitive skills. Statistical tests to determine success indicators predicting mathematical problem-solving performance revealed that mathematics self-efficacy does not contribute significantly to these variables and that metacognitive skills make the most decisive contribution, followed by mathematics attitude and mathematics beliefs. Hence, this study suggests that problem-solving should be included as an essential part of the mathematics matriculation syllabus to enable students to improve their problem-solving abilities.
\end{abstract}

Keywords: mathematics beliefs; mathematics attitude; mathematics selfefficacy and metacognitive skills; problem-solving performance

\section{Introduction}

The Malaysian Ministry of Education implemented steps for the transformation of education through the Malaysia Education Blueprint 2013_2025 to empower the nation's human capital with the expertise and skills of the 21st century and be among the top global players (Ministry of Education Malaysia, 2016). The 
government aims to develop the intelligence, critical thinking skills, leadership skills, language proficiency, ethics and spirituality and national identity of Malaysian children to enable them to thrive in the 21st century. In the 21st century, students will need to equip themselves with good communication, teamwork, imagination and innovation, critical thinking and problem-solving skills to achieve success (Warner \& Kaur, 2017).

The Malaysia Education Blueprint 2013-2025 (Shift 1) focuses on providing equal access to the Malaysian education standard to be at par with international standard. The ministry hopes that Malaysia will produce globally competitive students by benchmarking and setting the standard criteria for education systems by focusing on the students' learning practices and performances. In 2017, the blueprint was redrafted to introduce the revised Kurikulum Standard Sekolah Menengah (KSSM) and the revised Kurikulum Standard Sekolah Rendah (KSSR), which focus on advocating the knowledge and specific skills, such as, creative and innovative thinking, problem-solving and leadership. The new curriculum is designed based on international benchmarks to ensure that children born into the country's school system have the necessary skills to compete globally (Ministry of Education Malaysia, 2013). The enforcement will ensure that students will be capable of portraying the subject content while extrapolating the information and creatively connecting them to unfamiliar settings. The ministry will reasonably escalate the percentage of higher-order thinking questions with a minimum of 40\% questions in Ujian Pencapaian Sekolah Rendah (UPSR) and 50\% in Sijil Pelajaran Malaysia (SPM) to validate the effectiveness of the enforcement. The changes will hone the students to foster their creativity in handling the typical routines using different settings.

As problem-solving focuses on the teaching and learning of mathematics, the emphasis must not be at the secondary level only but also at the post-secondary level. The Ministry of Education provides a wide range of post-secondary education, including Matriculation, which is recognized as a credible foundation program for undergraduate programs in higher learning institutions in Malaysia and several overseas universities (Ministry of Education Malaysia, 2016). Hence, the matriculation mathematics syllabus was designed by considering the topics covered in secondary schools to strengthen and broaden their knowledge and skills in Mathematics and enable students to have complete and robust foundation to pursue programs in science, technology, social science and management (Matriculation Division, 2006).

Most studies among matriculation students have been conducted by other scholars (Buzzai et al. 1, 2020; Boğar, 2018). For example, Ong and Lim (2014) identify the factors that influence the matriculation students in mathematical problem solving, but they used Bayesian Network to analyse the causal relationships. This study will utilise an inferential research approach to explain and predict interrelationships between influential domain variables to fill this gap. 
The factors underlying this phenomenon, specifically among matriculation students need to be determined. Convincing the students to solve mathematical problems cannot be easily accomplished unless we know the critical aspect that could affect students' mathematics performance, such as mathematics beliefs, mathematics attitudes, metacognitive skills and mathematics self-efficacy. This study will utilize an inferential research approach to explain and predict interrelationships between influential domain variables to fill these gaps.

The government's vision is that children will never stop learning throughout their lives and eventually connect the dots and develop new knowledge (Ministry of Education Malaysia, 2013). Changing the education system and enhancing the teaching and learning environment will ideally create students who can master various essential cognitive abilities, including logical thinking, brainstorming, creative thinking and innovation. It is believed that the prominent students with the ability to solve problems will have a better future in their careers and lifetimes (Khalid, 2017). Thus, this study examined four success indicators that affect students' results in mathematical problem-solving significantly.

\subsection{Problem-Solving in Mathematics}

Problem-solving involves extensive skills in parallel to the curriculum, particularly in teaching and learning mathematics. Teaching mathematics topics through problem-solving focuses on problem-solving contexts and inquiryoriented environments (Khalid, 2017). Students who participate in problemsolving activities will experience mathematics' power by understanding and applying their knowledge to real-life problems (Tarmizi et al., 2015).

The aspects of human psychology, such as cognitive, affective, metacognitive and behaviour need to be emphasized from primary to tertiary levels to help students develop their mathematical problem solving skills (Mason, 2016). Additionally, the problem-solving process involves steps, such as determining how an issue can be addressed, strategizing the approach used and how much effort and timeframe set to obtain a solution (Tambunan, 2019). Students must also apply their knowledge in solving a problem, a process that would affect the deep understanding of mathematics and the choice of strategies (Liljedahl et al., 2016; Khalid, 2017).

Numerous studies have focused on students' characteristics towards their mathematical performance. These studies include exploring the difficulties that students faced in mathematics problem solving (Ayop \& Tarmizi, 2015). Several studies have also revealed that success indicators, such as mathematics beliefs (Rincon et al., 2020; Kamalimoghaddam et al., 2016), mathematics attitude, metacognitive and mathematics self-efficacy affect problem-solving (Özcan \& Gümüş, 2019; Kahramanoglu \& Deniz, 2017).

\subsubsection{Mathematics Belief}

Mathematics beliefs are defined as an individual's beliefs on mathematics that encourage his/her to make decisions regarding actions he/she will pursuit (Kloosterman et al., 1996). Mathematics beliefs have also been defined as students' conceptions of mathematics that they hold to be true either implicitly or explicitly 
and can influence them in their mathematics learning and mathematical problem solving (Wang et al., 2019). In this study, mathematics beliefs are defined as students' assumptions about mathematical problem solving and their mathematics learning approaches, which consist of five components. Kloosterman and Stage (1992) suggested these five components as listed in Table 1.

Table 1: Components of Mathematics Belief

\begin{tabular}{|l|l|}
\hline $\begin{array}{l}\text { Difficult } \\
\text { Problems }\end{array}$ & $\begin{array}{l}\text { Perceived ability in solving time-consuming mathematics } \\
\text { problems (Abedalaziz and Akmar, 2012). }\end{array}$ \\
\hline Steps & $\begin{array}{l}\text { Students assume that mathematical word problems cannot be } \\
\text { resolved using the procedural method (Barrett, 2016). }\end{array}$ \\
\hline Understanding & $\begin{array}{l}\text { The necessity for students to understand how to obtain solutions } \\
\text { (Prendergast et al., 2018). }\end{array}$ \\
\hline Word Problems & $\begin{array}{l}\text { An essential element of mathematics and deals with mathematics } \\
\text { discipline (Abedalaziz and Akmar, 2012). }\end{array}$ \\
\hline Effort & $\begin{array}{l}\text { Students believe that attempts to study can motivate them to } \\
\text { successfully solve mathematics problems (Prendergast et al., } \\
\text { 2018). }\end{array}$ \\
\hline
\end{tabular}

\subsubsection{Mathematics Attitude}

Mathematics attitude is defined as a positive attitude or personal temperament towards mathematics (Peteros et al., 2019). Mathematics attitude is also defined as an individual's emotional response towards mathematics, mathematics beliefs and behaviour towards mathematics (Öztürk et al., 2020). In this study, mathematics attitudes are defined as students' attitudes towards mathematics during the classroom learning process, which consist of four dimensions. Tapia and Marsh (2004) suggested the four components listed in Table 2.

Table 2: Components of Mathematics Attitude

\begin{tabular}{|l|l|}
\hline Self-confidence & $\begin{array}{l}\text { Students' sense of dread, anxiety and hate in hearing the word } \\
\text { mathematics (Simegn et al., 2018). }\end{array}$ \\
\hline Value & $\begin{array}{l}\text { The usefulness and relatedness of learning mathematics to } \\
\text { student's life situations (Kasimu \& Imoro, 2017). }\end{array}$ \\
\hline Enjoyment & $\begin{array}{l}\text { Students' feeling of pleasure in solving challenging mathematics } \\
\text { problems, willingness to participate in mathematics discussion and } \\
\text { excitement in the mathematics classroom (Simegn et al., 2018). }\end{array}$ \\
\hline Motivation & $\begin{array}{l}\text { Students' interest in learning mathematics and willingness to } \\
\text { further their knowledge in mathematics (Ajisuksmo \& Saputri, } \\
\text { 2017) }\end{array}$ \\
\hline
\end{tabular}

\subsubsection{Mathematics Self-Efficacy}

Mathematics self-efficacy can be defined as the assumptions or expectations of individuals that he/she can perform a particular task or overcome mathematical problems (Bandura, 1997). Mathematics self-efficacy is defined by students' beliefs on their potential to carry out any assignment or tasks needed for learning (Salim et al., 2018). This study defined mathematics self-efficacy as students' confidence in their abilities to accomplish various tasks, from understanding mathematical concepts to solving mathematical problems correctly. Mathematics self-efficacy was measured with four components as listed in Table 3. 
Table 3: Components of Mathematics Self-efficacy

\begin{tabular}{|l|l|}
\hline $\begin{array}{l}\text { Mastery } \\
\text { experience }\end{array}$ & $\begin{array}{l}\text { How students view and assess the previous achievement and their } \\
\text { judgments are amended according to these views (Doménech- } \\
\text { Betoret et al., 2017). }\end{array}$ \\
\hline $\begin{array}{l}\text { Vicarious } \\
\text { experience }\end{array}$ & $\begin{array}{l}\text { How students feel and observe peer or adult models' academic } \\
\text { skills helps them manipulate their experience (Gopal et al., 2018). }\end{array}$ \\
\hline $\begin{array}{l}\text { Social } \\
\text { persuasions }\end{array}$ & $\begin{array}{l}\text { Encouraging messages that students get from teachers, parents and } \\
\text { close friends can empower their confidence in academic } \\
\text { capabilities (Kandemir \& Akbaş-Perkmen, 2017). }\end{array}$ \\
\hline $\begin{array}{l}\text { Physiological } \\
\text { states }\end{array}$ & $\begin{array}{l}\text { Students' emotional condition (Kandemir \& Akbaş-Perkmen, } \\
\text { 2017). }\end{array}$ \\
\hline
\end{tabular}

\subsubsection{Metacognitive Skills}

Metacognitive skill was defined as an individual's power to deliberate and this skill is used to understand, plan, monitor, evaluate learning activities, summarise and reflect (Veenman \& van Cleef, 2019). Metacognitive skills can also be expressed as an individual's awareness to periodically monitoring whether he/ she has attained the goal and carrying out different strategies after selecting them if necessary (O'Neil \& Abedi, 1996). In this study, metacognitive skills are defined as students' awareness of the mathematical problem-solving process. As suggested by O'Neil \& Abedi, 1996, metacognitive skills consist of four components: planning, self-checking, cognitive strategy and awareness.

Table 4: Components of Metacognitive Skills

\begin{tabular}{|l|l|}
\hline Planning & $\begin{array}{l}\text { Learning options, target setting, inquisitiveness and way of doing } \\
\text { things (Loh \& Lee, 2019). }\end{array}$ \\
\hline Self-checking & $\begin{array}{l}\text { Students monitor their learning process to determine problems and } \\
\text { change strategies to achieve the goal (Hinojosa et al., 2020). }\end{array}$ \\
\hline $\begin{array}{l}\text { Cognitive } \\
\text { strategy }\end{array}$ & $\begin{array}{l}\text { Individual cognitive or affective strategies which needed during } \\
\text { the learning process (Hinojosa et al., 2020). }\end{array}$ \\
\hline Awareness & A process which is someone fully aware of (Loh \& Lee, 2019). \\
\hline
\end{tabular}

\subsection{Mathematical Problem-Solving Performance}

Mathematical problem solving is presumed to challenge and strengthen student's intellectual understanding and encourage the development of mathematics concepts (NCTM, 2010). Polya (1957) defined mathematical problem solving as finding a strategy around a hardship and identifying a solution to an unfamiliar problem. Accordingly, Amalia et al. (2017) discussed in detail the basic procedure in problem-solving, which include the following:

1. Describe the problem/problem statement

2. Strategize and develop the plan

3. Assess and decide the alternatives

4. Implement and seek for solution

Stylianides and Stylianides (2014) agree that mathematical problem solving provides an activity for students to think out of the box by relating the actual situation or actual data with the unknown. Therefore, this study's mathematical problem-solving performance is defined as the students' achievement in finding 
the best solution to a set of mathematical problem-solving tests. To evaluate this performance, the Mathematical Problem-Solving Test (MPST) has been adopted. Five mathematics problems based on the matriculation mathematics curriculum were filtered to ensure that only cover the Integration topic. This study's mathematics problems were the types of problems that had a clear structure. The problems also had a set of possible solutions and can be solved in writing. The problems selected are also challenging, but the context is still within what students have learned in their classrooms.

Identifying the success indicators that could predict their performance in mathematical problem-solving is necessary. Hence, a conceptual framework shown in Figure 1 was constructed involving four variables to measure the mathematical problem-solving performance. The conceptual framework was developed based on a combination of social cognitive theory (SCT), theory of planned behaviour (TPB) and model of mathematical problem solving, which had been drawn from the literature review. These variables were combined with modelling the relationship of students' affective indicators, metacognitive and mathematical problem-solving performance.

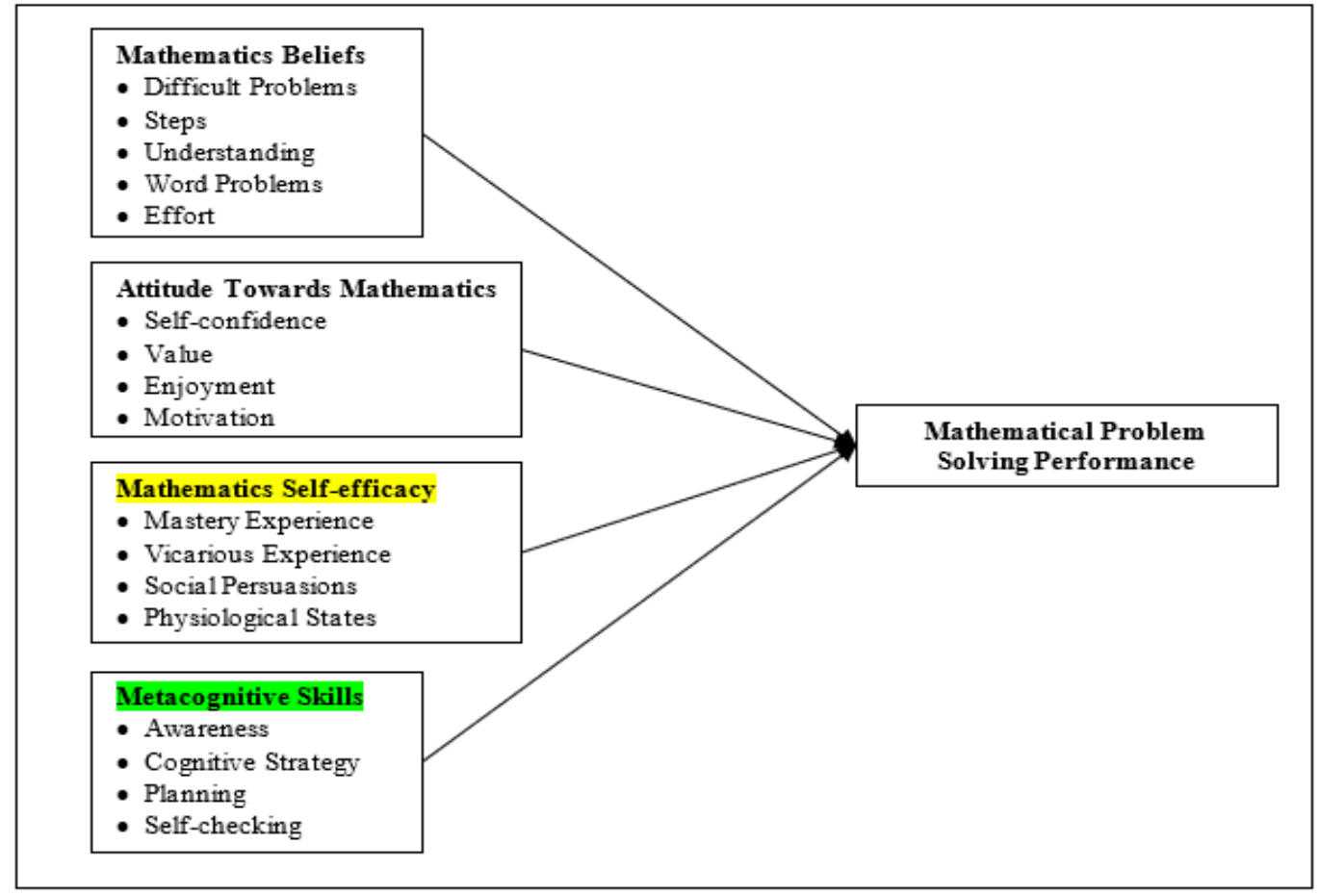

Figure 1: Conceptual Framework

\subsubsection{Success Indicators of Mathematical Problem-solving Performance}

Previous studies have validated that mathematics beliefs have a constructive influence on mathematics performance. A study on factors influencing mathematical problem-solving performance revealed a significant relationship between students' mathematics beliefs and their mathematical problem-solving performance (Deng et al., 2015). The second indicator, mathematics attitude, has also shown a significant effect on mathematics performance. In Wolkite Town, 240 students were surveyed using Attitude Towards Mathematics Scales (ATMS), 
which consists of five components, namely, Value, Male Domain, Enjoyment, Motivation and Confidence. The study found that mathematics attitude had the strongest positive significant correlation on mathematics achievement (Simegn \& Asfaw, 2018). Kandemir and Akbaş-Perkmen (2017) found that mastery experience, a source in mathematics self-efficacy, has a significant and positive influence on mathematics achievements. Consistent with another previous studies on mathematics self-efficacy, a study in Iran also showed that the third indicator has a strong effect on mathematics achievement (Kamalimoghaddam et al., 2016). Abdullah et al. (2017) focused on the role and effects of metacognitive skills strategy in mathematical activity found a positive and moderate significant correlation between metacognitive skills and mathematical problem-solving performance.

The remaining sections are structured as follows. In section 2, the objective and significance of this study are described. In Section 3, the details of the methodology are expounded. The survey results are presented in Section 4 and discussions are elaborated on in Section 5. Lastly, the concluding remarks are given in Section 6.

\section{Objectives}

In general, this study's motivation and rationale would add to the growing body of knowledge on mathematics problem-solving. It proposed to investigate the success indicators predicting mathematical problem-solving performance among Malaysian matriculation students. This paper provides a survey on the relationship between all indicators with their pros and cons. The objectives of this paper are as follows:

(i) To determine the relationship of mathematics beliefs, mathematics attitudes, mathematics self-efficacy and metacognitive skills on mathematical problem-solving performance among Malaysian matriculation students.

(ii) To identify success indicators that predicting mathematical problemsolving performance among Malaysian matriculation students.

The significance of this study are as follows:

(i) Post-secondary level education in Malaysia, especially the Matriculation Program, has been less explored than primary, secondary and tertiary education levels.

(ii) This study's findings can provide researchers and lecturers with insights into how beliefs, attitudes, metacognitive skills and selfefficacy affect how students transfer knowledge.

(iii) Analysing the success indicators that may influence the mathematical problem-solving performance will enrich information that can be used in improving mathematics education to researchers, lecturers, or policymakers.

\section{Methodology}

This study utilized a descriptive correlational design approach by collecting data obtained from a questionnaire. The design involved data collection and statistical 
analysis of numerical data (Ary et al., 2014) to characterise, clarify, anticipate or control the phenomena of interest (Mills \& Gay, 2016). This study also referred to Kamalimoghad who utilized the correlational design as a research methodology to determine the factors predicting mathematical problem-solving performance using various variables, including mathematics beliefs, mathematics attitude and metacognitive skills. Correlational design is a statistical procedure of correlational analysis in which researchers measure the degree of association or relationship among variables in a single group of subjects (Ary et al., 2014).

A set of questionnaires and a mathematics test were used as instruments in this study. Denscombe (2010) pointed out that questionnaire is suitable for any research with a large sample size from different locations. Therefore, standardized similar questions are required from the respondents. Data on mathematics beliefs, mathematics attitude, mathematics self-efficacy and metacognitive skills were obtained from students' ratings on the questionnaire items. Simultaneously, based on the total marks of a mathematics test, we measured the mathematical problem-solving performance. The results that adequately indicate significant relationships among the five variables would serve as strong evidence to carry out the next objective, i.e., prediction, using correlational analysis.

\subsection{Populations}

This quantitative correlational study employed a cluster sampling procedure. The sample for this study comprised of matriculation students under the Ministry of Education in three zones (North, Central and South). The North zone consists of four matriculation colleges namely, Kolej Matrikulasi Perlis, Kolej Matrikulasi Kedah, Kolej Matrikulasi Pulau Pinang and Kolej Matrikulasi Perak. The Central zone consists of five matriculation colleges namely, Kolej Matrikulasi Selangor, Kolej Matrikulasi Negeri Sembilan, Kolej Matrikulasi Kelantan, Kolej Matrikulasi Sarawak and Kolej Matrikulasi Labuan while the South zone has three matriculation colleges namely, Kolej Matrikulasi Melaka, Kolej Matrikulasi Johor and Kolej Matrikulasi Pahang.

Based on the total population identified as 18717 students from the matriculation program across Malaysia, the sample size calculation was obtained using Cochran's (1977) formula as 263. Therefore, the minimum sample size required, according to Cochran (1977,) is 263. Fraenkel et al. (2016) mentioned that a minimum sample of 30 should be generally acceptable to establish the existence of a relationship for a correlational study. However, for educational and social research studies, the response rate using surveys as the data collection method is usually below 100\% (Barlett et al., 2001). Hence, Salkind (2012) recommended oversampling by $40 \%$ to $50 \%$ to account for lost respondents and uncooperative respondents. Hence, in this study, the sample size was increased by $40 \%$ of the original number of the sample size calculated above. The addition to the sample was 105 students $(40 \% \times 263)$. Therefore, this study's total sample size was 368 to ensure that an adequate sample was used in this study.

A total of 368 students from the matriculation program under the Ministry of Education Malaysia were selected randomly. A list of colleges in the North, 
Central and South zones was acquired and based on random sampling, three colleges were chosen for the actual data collection process. The selected colleges were Kolej Matrikulasi Perak (North zone), Kolej Matrikulasi Negeri Sembilan (Central zone) and Kolej Matrikulasi Melaka (South zone). The sampling strategy process is shown in Table 5.

Table 5: Matriculation Colleges in Malaysia

\begin{tabular}{|c|c|c|c|c|}
\hline Colleges & $\begin{array}{l}\text { No. of } \\
\text { Students }\end{array}$ & $\begin{array}{c}\text { Percentage } \\
(\%)\end{array}$ & $\begin{array}{l}\text { Number of } \\
\text { samples } \\
\text { required }\end{array}$ & $\begin{array}{c}\text { Additional } \\
40 \%\end{array}$ \\
\hline \multicolumn{5}{|l|}{ North } \\
\hline Kolej Matrikulasi Perlis & 1,007 & & & \\
\hline Kolej Matrikulasi Kedah & 1,708 & & & \\
\hline Kolej Matrikulasi Pulau & 1,943 & & & \\
\hline Pinang & & 35 & 92 & 129 \\
\hline Kolej Matrikulasi Perak & 1,817 & & & \\
\hline Total & 6,475 & & & \\
\hline \multicolumn{5}{|l|}{ Central } \\
\hline Kolej Matrikulasi & 1,718 & & & \\
\hline \multicolumn{5}{|l|}{ Selangor } \\
\hline Kolej Matrikulasi Negeri & 1,645 & & & \\
\hline Sembilan & 1403 & 36 & 95 & 132 \\
\hline Kelantan & 1,403 & 36 & 90 & 132 \\
\hline Kolej Matrikulasi & 119 & & & \\
\hline Sarawak & 1,918 & & & \\
\hline \multicolumn{5}{|l|}{ Kolej Matrikulasi Labuan } \\
\hline Total & 6,803 & & & \\
\hline \multicolumn{5}{|l|}{ South } \\
\hline Kolej Matrikulasi Melaka & 1,616 & & & \\
\hline \multicolumn{5}{|l|}{ Kolej Matrikulasi Johor } \\
\hline Kolej Matrikulasi Pahang & 2,058 & 29 & 76 & 107 \\
\hline & 1,765 & & & \\
\hline Total & 5,439 & & & \\
\hline Overall Total & 18,717 & 100 & 263 & 368 \\
\hline
\end{tabular}

\subsection{Instrumentation}

Instrumentation involves designing the instruments and procedures of data collection (Fraenkel et al., 2016). This research instrument was a structured questionnaire composed of three parts, namely, Parts A, B and C. The number of items and sources for each construct in the questionnaire is listed in Table 6.

In Part B, respondents were given options by using a five-point Likert scale ranging from Strongly Disagree (1), Disagree (2), Moderately Agree (3), Agree (4) and Strongly Agree (5) to measure their agreement on the questionnaire statements. All five items in Part C in section 1 were scored in three categories: understanding, planning a solution and getting answers. Each item was given six points with a total score of 30 . 
Table 7 shows the problem-solving marking scheme details to assess mathematical problem-solving questions in this study. The percentages of total scores from each step of the marking scheme were used to determine students' mathematical problem-solving performance.

Table 6: Distribution of Items in Each Section and the Sources

\begin{tabular}{|c|c|c|c|}
\hline Part/ Section & Components & $\begin{array}{l}\text { No. of } \\
\text { Item }\end{array}$ & Source \\
\hline $\begin{array}{l}\text { Part A } \\
\text { Section } 1\end{array}$ & Demographic Information & 5 & $\begin{array}{l}\text { Self- } \\
\text { developed }\end{array}$ \\
\hline $\begin{array}{l}\text { Part B } \\
\text { Section } 1\end{array}$ & \begin{tabular}{ll}
\multicolumn{2}{l}{ Mathematics Beliefs } \\
- & Difficult Problems \\
- & Steps \\
- & Understanding \\
- & Word Problems \\
- & Effort
\end{tabular} & $\begin{array}{c}28 \\
6 \\
4 \\
6 \\
6 \\
6\end{array}$ & $\begin{array}{l}\text { Kloosterman } \\
\text { \& Stage (1992) }\end{array}$ \\
\hline Section 2 & \begin{tabular}{ll}
\multicolumn{2}{l}{ Mathematics Attitudes } \\
- & Self-confidence \\
- & Value \\
- & Enjoyment \\
- & Motivation \\
\end{tabular} & $\begin{array}{l}40 \\
15 \\
10 \\
10 \\
5\end{array}$ & $\begin{array}{l}\text { Tapia \& } \\
\text { Marsh (2004) }\end{array}$ \\
\hline Section 3 & $\begin{array}{l}\text { Mathematics Self-efficacy } \\
\text { - Mastery Experience } \\
\text { - Vicarious Experience } \\
\text { - Social Persuasions } \\
\text { - Physiological States }\end{array}$ & $\begin{array}{c}24 \\
6 \\
6 \\
6 \\
6 \\
\end{array}$ & $\begin{array}{l}\text { Usher \& } \\
\text { Pajares (2009) }\end{array}$ \\
\hline $\begin{array}{l}\text { PART C } \\
\text { Section } 1\end{array}$ & $\begin{array}{l}\text { Mathematical Problem } \\
\text { Solving Performance }\end{array}$ & 5 & $\begin{array}{l}\text { Self- } \\
\text { developed }\end{array}$ \\
\hline Section 2 & $\begin{array}{l}\text { Metacognitive Skills } \\
\text { - Awareness } \\
\text { - Cognitive Strategy } \\
\text { - Planning } \\
\text { - Self-checking } \\
\end{array}$ & $\begin{array}{c}20 \\
5 \\
5 \\
5 \\
5 \\
118\end{array}$ & $\begin{array}{l}\text { O'Neil \& }^{\prime} \text { Abedi (1996) }\end{array}$ \\
\hline
\end{tabular}

Table 7: Marking Scheme Details

\begin{tabular}{ccll}
\hline Stages & Scores & \multicolumn{1}{c}{ Characteristics } & \multicolumn{1}{c}{ Description } \\
\hline & 0 & $\begin{array}{l}\text { Complete } \\
\text { misunderstanding }\end{array}$ & $\begin{array}{l}\text { Lack of comprehension problem } \\
\text { Not able to identify important given } \\
\text { data. }\end{array}$ \\
$\begin{array}{l}\text { Misunderstood/ misinterpreted part of } \\
\text { the data, partially understand goals and } \\
\text { hidden data. } \\
\text { Ability to take information and } \\
\text { translate it in the mathematical model, } \\
\text { fully retrieve given and hidden data. }\end{array}$ \\
\hline
\end{tabular}




\begin{tabular}{|c|c|c|c|}
\hline \multirow{3}{*}{ 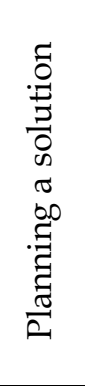 } & 0 & No & $\begin{array}{l}\text { Wrong integration procedure, not able } \\
\text { to put constant of integration. }\end{array}$ \\
\hline & 1 & $\begin{array}{l}\text { plan } \\
\text { Partially correct plan }\end{array}$ & $\begin{array}{l}\text { Accurate interpretation up to a certain } \\
\text { point but fail to strategize }\end{array}$ \\
\hline & 2 & $\begin{array}{l}\text { Plan led to a correct } \\
\text { solution }\end{array}$ & $\begin{array}{l}\text { Execute the plan, translate the plan into } \\
\text { series of appropriate mathematical } \\
\text { actions, successful findings. }\end{array}$ \\
\hline \multirow{3}{*}{ 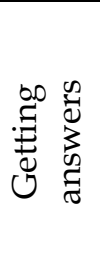 } & 0 & $\begin{array}{l}\text { No answer/ wrong } \\
\text { answer }\end{array}$ & Cannot execute integration steps. \\
\hline & 1 & $\begin{array}{l}\text { Copying error; } \\
\text { computational error }\end{array}$ & Mathematical/ computational error. \\
\hline & 2 & $\begin{array}{l}\text { The correct answer, } \\
\text { the correct label }\end{array}$ & Solution complete, no error in response. \\
\hline
\end{tabular}

Table 8 shows the distribution of the students' scores and their test performance level. In Section 2, 25 items were measured on a five-point Likert scale. The scales for items in this section were Never (1), Rarely (2), Sometimes (3), Often (4) and Always (5).

Table 8: Distribution of Students Score and Performance Level

\begin{tabular}{ll}
\hline Scores & Level \\
\hline 0.00 to 36.72 & Very Low \\
36.73 to 46.68 & Low \\
46.69 to 56.75 & Medium \\
56.76 to 66.86 & High \\
66.87 to 100.00 & Very High \\
\hline \multicolumn{2}{c}{ Adapted from: (Lee et al., 2013) }
\end{tabular}

\subsection{Reliability}

An instrument's reliability is the degree of coherence or consistency, which can measure the same variables even if used in different samples, times and places (Ary et al., 2014). In this pilot study, the reliability measurement was used to assess the internal coherence. Internal coherence refers to the items that comprise the scale by measuring the same bottom-line attributes (Pallant, 2020). The reliability analysis was performed on an instrument using Cronbach's Alpha coefficient in the IBM SPSS Statistics software. All constructs tested were considered reliable because the Cronbach's Alpha value was more significant than 0.50 , which is congruent with the acceptable value for reliability as indicated by Hinton et al. (2014). The Cronbach's Alpha reliability coefficients for the pilot and actual studies are summarized as in Table 9. 
Table 9: Cronbach's Alpha Coefficient

\begin{tabular}{llcccc}
\hline \multicolumn{1}{c}{ Part } & \multicolumn{1}{c}{ Variable } & $\begin{array}{c}\text { No. of } \\
\text { Items } \\
\text { before Pilot } \\
\text { Study }\end{array}$ & $\begin{array}{c}\text { No. of } \\
\text { Items after } \\
\text { Pilot } \\
\text { Study }\end{array}$ & $\begin{array}{c}\text { Pilot } \\
\text { Study } \\
\text { (n=99) }\end{array}$ & $\begin{array}{c}\text { Actual } \\
\text { Study } \\
\text { (n=312) }\end{array}$ \\
\hline $\begin{array}{l}\text { Part A } \\
\text { Section 1 }\end{array}$ & $\begin{array}{l}\text { Demographic } \\
\text { Information }\end{array}$ & 5 & 5 & - & - \\
$\begin{array}{l}\text { Part B } \\
\text { Section 1 }\end{array}$ & Mathematics Beliefs & 30 & 28 & .615 & .652 \\
Section 2 & Mathematics Attitudes & 40 & 40 & .952 & .959 \\
Section 3 & $\begin{array}{l}\text { Mathematics Self- } \\
\text { efficacy }\end{array}$ & 24 & 24 & .827 & .928 \\
PART C & $\begin{array}{l}\text { Mathematical Problem- } \\
\text { Section 1 }\end{array}$ & 5 & 5 & .839 & .772 \\
Section 2 & $\begin{array}{l}\text { Melving Performance } \\
\text { Metacognitive Skills }\end{array}$ & 20 & 20 & .898 & .922 \\
\hline
\end{tabular}

\section{Analysis and Results}

The relationship between the four success indicators for mathematical problem solving and mathematics achievement was calculated utilising the Pearson product-moment correlation technique. Then, multiple regression analysis was performed to identify the best predictors of the four indicators on the mathematical problem-solving in mathematics achievements. Based on Hair et al. (2010), the normality, linearity, homoscedasticity assumptions had been met.

\subsection{Demographic Information}

The respondents' general demographic information is given in Table 10. A total of 368 matriculation students participated in this study, composed of 125 (34.0\%) male students and $243(66.0 \%)$ female students. Therefore, a significant majority of the respondents were females. Ethnic groups were categorized into four subcategories including Malay respondents (322 respondents, 87.5\%), 30 Indian respondents $(8.1 \%), 15$ Chinese respondents $(4.2 \%)$ and only one respondent from others. The majority were Malay respondents because the Ministry of Education's Matriculation Programme is a preparatory program for Bumiputera students with only $10 \%$ non-Bumiputera students.

In terms of mathematics grades in PSPM1, 120 respondents (32.7\%) earned an A and $15.7 \%$ (58 respondents) earned A- , about 3.5\% (13 respondents) and 0.6\% (two respondents) earned $\mathrm{C}$ and $\mathrm{C}$ - for mathematics, respectively. As for the number of revision hours for the mathematics subject, most of the respondents (178 respondents, $48.4 \%$ ) had less than an hour of mathematics revision per day. Moreover, only 18 respondents $(4.8 \%)$ had four to five hours of mathematics revision per day. 
Table 10: Demographic Information

\begin{tabular}{cccc}
\hline Demography & Category & $\begin{array}{c}\text { Number of } \\
\text { Respondents }\end{array}$ & $\begin{array}{c}\text { Percentage } \\
\mathbf{( \% )}\end{array}$ \\
\hline Gender & Male & 125 & 34.0 \\
Race & Female & 243 & 66.0 \\
& Malay & 322 & 87.5 \\
& Chinese & 15 & 4.2 \\
& Indian & 30 & 8.1 \\
Mathematics & Others & 1 & 0.2 \\
Grade & A & 120 & 32.7 \\
& A- & 58 & 15.7 \\
& B+ & 65 & 17.6 \\
& B & 60 & 16.3 \\
& B- & 26 & 7.1 \\
& C+ & 24 & 6.4 \\
Hours of & C & 13 & 3.5 \\
Revision & C- & 2 & 0.6 \\
& $0-1$ hour/day & 178 & 48.4 \\
& 2-3 hours/day & 172 & 46.8 \\
& $4-5$ hours/day & 18 & 4.8 \\
\hline
\end{tabular}

\subsection{Statistical Analysis}

The means of all variable items were summed up and averaged to obtain the overall mean for each variable. The mean value of less than 3.00 was categorized as low and the value that fell between 3.01 to 5.00 was classified as high. Table 11 shows the means (M) and standard deviations (SD) of the respondents' responses on the variables investigated in this study. The average mean for the responses on all variables was $3.83(\mathrm{SD}=0.49)$. The highest mean rating was attained on mathematics attitude $(\mathrm{M}=3.91, \mathrm{SD}=0.57)$, followed by metacognitive skills $(\mathrm{M}=3.84, \mathrm{SD}=0.52)$, then by mathematics beliefs $(\mathrm{M}=3.80, \mathrm{SD}=0.28)$ and lastly, mathematics self-efficacy $(\mathrm{M}=3.75, \mathrm{SD}=0.59)$. The results implied that matriculation students perceived themselves as demonstrating high mathematics attitude, metacognitive skills, mathematics beliefs and mathematics self-efficacy towards mathematical problem-solving performance.

Table 11: Mean and Standard Deviation

\begin{tabular}{lccc}
\hline \multicolumn{1}{c}{ Variable } & Mean & SD & Category \\
\hline Mathematics Beliefs & 3.80 & 0.28 & High \\
Mathematics Attitude & 3.91 & 0.57 & High \\
Mathematics Self-efficacy & 3.75 & 0.59 & High \\
Metacognitive Skills & 3.84 & 0.52 & High \\
\hline Overall Mean and & \multirow{2}{*}{3.83} & 0.49 & High \\
Standard Deviation & & & \\
\hline
\end{tabular}

The Pearson correlation analysis was performed to determine any significant relationships among mathematics beliefs, mathematics attitude, metacognitive skills, mathematics self-efficacy and mathematical problem-solving performance. The results of Pearson's correlation analysis are presented in Table 12. 
The results showed significant relationships at the 0.01 level of significance between the independent and dependent variables. Significant relationships were observed between mathematics beliefs $\left(\mathrm{r}=0.448^{* *}, \mathrm{p}=0.000\right)$, mathematics attitude $\left(\mathrm{r}=0.489^{* *}, \mathrm{p}=0.000\right)$, metacognitive skills $\left(\mathrm{r}=0.455^{* *}, \mathrm{p}=0.000\right)$, mathematics selfefficacy $\left(\mathrm{r}=0.484^{* *}, \mathrm{p}=0.000\right)$ and mathematical problem solving performance. All the relationships were of moderate strengths (Lodico et al., 2010).

Table 12: Results of Pearson Correlation Coefficients

\begin{tabular}{|c|c|c|c|c|c|}
\hline & & $\begin{array}{l}\text { Mathematics } \\
\text { Beliefs }\end{array}$ & $\begin{array}{l}\text { Mathematics } \\
\text { Attitude }\end{array}$ & $\begin{array}{l}\text { Metacognitive } \\
\text { Skills }\end{array}$ & $\begin{array}{l}\text { Mathematics } \\
\text { Self-efficacy }\end{array}$ \\
\hline Mathematics & $\mathrm{r}$ & $0.448^{* *}$ & $0.489 * *$ & $0.455^{\star * *}$ & $0.484^{* *}$ \\
\hline $\begin{array}{l}\text { Problem } \\
\text { Solving } \\
\text { Performance }\end{array}$ & $\begin{array}{c}\text { Sig. } \\
(2- \\
\text { tailed) }\end{array}$ & 0.000 & 0.000 & 0.000 & 0.000 \\
\hline
\end{tabular}

${ }^{* *}$ Correlation is significant at the 0.01 level

The following model summary table (Table 13) shows Malaysia's multiple correlation coefficient was 0.558 and the $\mathrm{R}^{2}$ value was 0.311 . The $\mathrm{R}^{2}$ value indicated how much the model disclosed the variance in the dependent variable. The $\mathrm{R}^{2}$ value obtained was 0.311 , indicating that $31.1 \%$ of the mathematical problemsolving performance variance could be explained by the model containing the combination of the independent variables.

Table 13: Model Summary

\begin{tabular}{cccc}
\hline $\mathbf{R}$ & R Square & Adjusted R Square & Std. Error of the Estimate \\
\hline 0.558 & 0.311 & 0.305 & 1.45160 \\
\hline
\end{tabular}

Table 14 presents the Analysis of Variance (ANOVA) for the multiple regression model. The F-test in the ANOVA table test identified whether the regression model fits the data. The F-test results showed that the independent variables significantly predicted the dependent variable $[\mathrm{F}(3,311)=46.402, \mathrm{p}=0.000]$ at a significance level of 0.05 .

Table 14: ANOVA

\begin{tabular}{lccccc}
\hline Model & Sum of Squares & df & Mean Square & F & Sig. \\
\hline Regression & 293.325 & 3 & 97.775 & 46.402 & 0.000 \\
Residual & 648.995 & 308 & 2.107 & & \\
Total & 942.320 & 311 & & & \\
\hline
\end{tabular}

The result of the multiple linear regression shown in Table 15 revealed that mathematics beliefs $(t=2.304, p<0.05)$, mathematics attitude $(t=3.916, p<0.05)$ and metacognitive skills $(\mathrm{t}=4.849, \mathrm{p}<0.05)$ had unique and statistically significant contribution to the mathematical problem-solving performance. However, mathematics self-efficacy did not contribute significantly and was excluded from the regression, which might be because mathematics self-efficacy overlapped with other independent variables in the model (Pallant, 2020).

The data in Table 15 show that the beta $(\beta)$ value for metacognitive skills $(\beta=0.284)$ 
was the most significant coefficient followed by mathematics attitude $(\beta=0.251)$ and mathematics beliefs $(\beta=0.132)$. These implied metacognitive skills were the most vital unique contributors in explaining mathematical problem-solving performance. The model indicated with each increase of one standard deviation in metacognitive skills and mathematical problem-solving performance would lead to an increment by 0.284 standard deviation units. With an increase of one standard deviation in mathematics attitude, mathematical problem-solving understanding would increase by 0.251 standard deviation units. Likewise, with every increase of one standard deviation in mathematics beliefs, mathematical problem-solving performance would lead to an increment of 0.132 standard deviation units.

Table 15: Results of Regression Analysis

\begin{tabular}{lccccc}
\hline & \multicolumn{2}{c}{$\begin{array}{c}\text { Unstandardized } \\
\text { Coefficients }\end{array}$} & $\begin{array}{c}\text { Standardized } \\
\text { Coefficients }\end{array}$ & \\
\hline Independent Variable & $\mathbf{B}$ & Std. Error & Beta & $\mathbf{t}$ & Sig. \\
\hline (Constant) & -7.282 & 1.237 & & -5.886 & 0.000 \\
Mathematics Beliefs & 0.906 & 0.393 & 0.132 & 2.304 & 0.022 \\
Mathematics Attitude & 0.763 & 0.195 & 0.251 & 3.916 & 0.000 \\
Metacognitive Skills & 0.946 & 0.195 & 0.284 & 4.849 & 0.000 \\
$\begin{array}{l}\text { Mathematics Self- } \\
\text { efficacy }\end{array}$ & & & 0.088 & 0.897 & 0.370 \\
\hline
\end{tabular}

\section{Discussion}

This study aimed to identify the relationship between students' mathematics beliefs, mathematics attitudes, mathematics self-efficacy and metacognitive skills towards mathematical problem-solving performance among Malaysian matriculation students.

Mathematics beliefs referred to students' thoughts about mathematics that encourage them to make decisions regarding their actions. It is an essential component of students' participation in mathematics learning activities and mathematics performance. The findings of this study indicated that the respondents had a high level of mathematics beliefs. However, among the five components, respondents believe that efforts can enhance their mathematics ability and succeed in mathematics subjects. They agreed that studying hard could improve their mathematics ability and enable them to become more competent in solving mathematics problems. Respondents perceived that understanding why a particular procedure was correct is essential rather than getting the right answer. Conjointly, the respondents also believed they would not surrender easily while solving the time-consuming mathematics problem.

In this study, mathematics attitude refers to students' attitude towards mathematics during the learning process in the classroom. The four components used to evaluate mathematics attitude were self-confidence, value, enjoyment and motivation. The finding of this study revealed that the respondents concurred that mathematics was one of the remarkably crucial subjects to learn and that studying 
mathematics at an advanced level was appealing because of the challenge of solving mathematics questions. They also view mathematics as an exciting subject and they usually enjoyed learning mathematics in college because they gained a sense of satisfaction after solving mathematics problems. The students tended to believe they had self-confidence and a positive self-concept on their mathematics performance.

Mathematics self-efficacy is outlined as personal persuasions or impressions that an individual has the power to perform a specific task or solving mathematics problems. The four components used to evaluate mathematics self-efficacy were mastery experience, vicarious experience, social persuasions and physiological states. A high level of mathematics self-efficacy was identified in this study because respondents perceived that seeing friends do better than them when solving mathematics problems could motivate them to do better. Moreover, seeing adults perform well in mathematics could also encourage them to do better.

Metacognitive skills refers to students' ability to plan, monitor, evaluate and control their cognitive strategies during mathematical problem-solving activity. Various components are used to assess students' metacognitive skills in mathematical problem solving, including planning, self-checking, mental approach and awareness. The results showed that students' planning skills were at its highest level compared to the self-checking, awareness and cognitive strategy. The highest mean in planning skills suggested that respondents preferred to use planning skills compared to other metacognitive skills and indicated that would try to comprehend the mathematics problems before attempting to solve them fully. They also checked their working solutions, which caused them to correct the mistakes they made.

This study has several limitations. The study was limited and focused on students of the Matriculation Division, Ministry of Education Malaysia. Students' mathematical problem-solving in matriculation colleges may not relate to other subjects and another level as primary and tertiary education. Hence, the generalization of the results obtained may not be appropriate.

because it involves a survey, the data are self-reported and gathered using questionnaires and tests set. The findings are based on respondents' self-reports, which is an obvious limitation to the study. Moreover, the present study determined students' mathematics beliefs, mathematics attitudes, metacognitive skills and mathematics self-efficacy on students' mathematical problem-solving performance. Other factors that may affect students' mathematical problemsolving performances such as gender, parents' education and socioeconomic context, were not explored. Hence, only certain parts of topics for post-secondary education level, especially from the matriculation syllabus of mathematics, were studied.

Mathematical problem-solving refers to students' activity in finding a mathematics problem and their ability to relate the unknown with the actual 
situation or data. In this study, mathematical problem-solving performance referred to students' performance in solving mathematics problems. Based on the students' performance level analysis, most students' performance level in mathematical problem solving are very low. The inadequate level in mathematical problem-solving performance suggested that the students are very poor in solving the mathematics problems, which might be due to a lack of problem-solving practice for the students in the classroom. Therefore, this study suggested that problem-solving should be included as an essential part of the mathematics matriculation syllabus to provide students with the space to upgrade their problem-solving abilities. By teaching through a problem-solving learning environment, students are expected to have greater mathematics conceptual understanding that can help them become good problem solvers.

\section{Conclusion}

Students' mathematics beliefs, attitude towards mathematics, mathematics selfefficacy and metacognitive skills in mathematical problem solving were categorized as high. However, mathematical problem-solving performance was classified as low. Correlation analysis was used to identify the relationship between mathematics beliefs, attitude towards mathematics, mathematics selfefficacy and metacognitive skills towards mathematical problem-solving performance. The findings indicated a significant positive correlation between mathematics beliefs, attitude towards mathematics, mathematics self-efficacy and metacognitive skills towards mathematical problem-solving performance. Multiple regression analysis was used to identify the best predictor of mathematical problem-solving performance. The findings revealed that the metacognitive abilities had the most substantial contribution, followed by mathematics attitude and mathematics beliefs. However, among these variables, mathematics self-efficacy did not contribute significantly. These results identified that the final model with three predictor variables explained $31.1 \%$ of the mathematical problem-solving performance variation.

\section{References}

Abdullah, A. H., Rahman, S. N. S. A., \& Hamzah, M. H. (2017). Metacognitive skills of Malaysian students in non-routine mathematical problem-solving. Bolema: Boletim de Educação Matemática, 31(57), 310-322. https://doi.org/10.1590/1980$4415 \mathrm{v} 31 \mathrm{n} 57 \mathrm{a} 15$

Abedalaziz, N., \& Akmar, S. N. (2012). Epistemology beliefs about mathematical problem solving among Malaysian students. OIDA International Journal of Sustainable Development, 5(1), 59-74.

Ajisuksmo, C., \& Saputri, G. (2017) The Influence of Attitudes towards Mathematics, and Metacognitive Awareness on Mathematics Achievements. Creative Education, 8, 486-497. http://doi.org/10.4236/ce.2017.83037

Amalia, E., Surya, E., \& Syahputra, E. (2017). The effectiveness of using problem-based learning (PBL) in mathematics problem-solving ability for junior high school students. International Journal of Advance Research and Innovative Ideas in Education, 3(2), 3402-3406.

Ary, D., Jacobs, L. C., Sorensen, C. K., \& Walker, D. (2014). Introduction to research in education (9th ed.). Belmont, CA: Wadsworth, Cengage Learning. 
Ayop, R. A., \& Ahmad Tarmizi, R. (2015). Pre-university Students' Difficulties in Problem Solving by Using Q-methodology. Jurnal Pendidikan Sains dan Matematik Malaysia, 5(2), 1-11.

Bandura, A. (1997). Self-efficacy: The exercise of control. New York: W.H. Freeman.

Barrett, L. L. (2016). Development and Validation of the Mathematical Problem-solving Dispositions and Beliefs Scale. [PhD Dissertations, Kennesaw State University].

Barlett, J. E., Kotrlik, J. W., \& Higgins, C. C. (2001). Organizational research: Determining appropriate sample size in survey research. Information Technology, Learning, and Performance Journal, 19(1), 43-50.

Buzzai, C., Filippello, P., Puglisi, B., Mafodda, A. V., \& Sorrenti, L. (2020). The relationship between mathematical achievement, mathematical anxiety, perfectionism, and metacognitive abilities in Italian students. Mediterranean Journal of Clinical Psychology, 8(3).1-18

Boğar, Y. (2018). Exploring 6 th grade students'scientific epistemological beliefs and metacognitive awareness regarding achievement level [Doctoral dissertation, Middle East Technical University].

Deng, F., Tay, E. G., Toh, T. L., Leong, Y. H., Quek, K. S., Toh, P. C., ... \& Ho, F. H. (2015). Enhancing Student Beliefs about Mathematical Problem Solving: Effects of a Problem-Solving based Intervention. Research in Mathematical Education, 19(1), 1941.

Denscombe, M. (2010). The Good Research Guide for Small-Scale Social Research Project (4th ed.). New York: Open University Press.

Doménech-Betoret, F., Abellán-Roselló, L., \& Gómez-Artiga, A. (2017). Self-efficacy, Satisfaction, and Academic Achievement: The Mediator Role of Students' Expectancy-Value Beliefs. Frontiers in Psychology, 8(2), 1-12. https://doi.org/10.3389/fpsyg.2017.01193

Fraenkel, J. R., Wallen, N. E., \& Hyun, H. H. (2016). How to design and evaluate research in education (9th ed.). New York: McGraw Hill Higher Education.

Gopal, K., Salim, N. R., \& Ayub, A. F. M. (2018, November). Influence of Self-efficacy and Attitudes Towards Statistics on Undergraduates' Statistics Engagement in A Malaysian Public University. In Journal of Physics: Conference Series (Vol. 1132, No. 1, p. 012042).

Hair, J. F., Black, W. C., Babin, B. J., \& Anderson, R. E. (2010). Multivariate Data Analysis (7th ed.). New Jersey, USA: Pearson Prentice Hall.

Hinojosa, L. M. M., Rodriguez, M. C., \& Paez, C. A. O. (2020). Measurement of Metacognition: Adaptation of Metacognitive State Inventory in Spanish to Mexican University Students. European Journal of Educational Research, 9(1), 413421.

Hinton, P. R., McMurray, I., \& Brownlow, C. (2014). SPSS Explained (2 ${ }^{\text {nd }}$ ed.). New York: Routledge.

Kahramanoglu, R., \& Deniz, T. (2017). An investigation of The Relationship Between Middle School Students' Metacognitive Skills, Mathematics Self-Efficacy, and Mathematics Achievement. Inonu University Journal of the Faculty of Education, 18(3), 189-200. https://doi.org/10.17679/inuefd.334285

Kamalimoghaddam, H., Ahmad Tarmizi, R., Ayub, A. F. M., \& Jaafar, W. M. W. (2016). The Influences of Mathematics Beliefs on Mathematics Achievement Through Mathematics Self-Efficacy: A Structural Equation Model. Communication in Mathematical Modeling and Applications, 51(1), 44-51.

Kandemir, M. A., \& Akbaş-Perkmen, R. (2017). Examining Validity of Sources of Mathematics Self-Efficacy Scale in Turkey. European Journal of Education Studies. 3(11), 69-88. https://doi.org/10.5281/zenodo.1041845. 
Kasimu, O., \& Imoro, M. (2017). Students' Attitudes Towards Mathematics: The Case of Private and Public Junior High Schools in The East Mamprusi District, Ghana. IOSR Journal of Research \& Method in Education (IOSR-JRME), 7(5), 38-43. https:// doi.org/10.9790/7388-0705063843

Khalid, M. (2017). Fostering problem solving and performance assessment among Malaysian mathematics teachers. Sains Humanika, 9(1-2), 51-55. https:// doi.org/10.11113/sh.v9n1-2.1098

Kloosterman, P., Raymond, A. M., \& Emenaker, C. (1996). Students' Beliefs about Mathematics: A three-year Study. The Elementary School Journal, 97(1), 39-56.

Kloosterman, P., \& Stage, F. K. (1992). Measuring Beliefs about Mathematical Problem Solving. School Science and Mathematics, 92(3), 109-115.

Lee, J. H., Abdullah, F. A. P., \& Bunyamin, M. A. H. (2013). Aplikasi konsep fizik dalam menyelesaikan masalah yang berasaskan STEM bagi pelajar tingkatan enam atas. In 2nd International Seminar on Quality and Affordable Education (pp. 470-481). Universiti Teknologi Malaysia, Malaysia.

Liljedahl, P., Santos-Trigo, M., Malaspina, U., \& Bruder, R. (2016). Problem Solving in Mathematics Education. Switzerland: Springer International Publishing.

Lodico, M. G., Spaulding, D. T., \& Voegtle, K. H. (2010). Methods in Educational Research: From theory to practice (Vol. 28). John Wiley \& Sons.

Loh, M. Y., \& Lee, N. H. (2019). The Impact of Various Methods in Evaluating Metacognitive Strategies in Mathematical Problem Solving. In Mathematical Problem Solving (pp. 155-176). Springer, Cham. ttps:/ / doi.org/10.1007/978-3-03010472-6_8

Mason, J. (2016). Part 1 Reaction: Problem Posing and Solving Today. In P. Felmer, E. Pehkonen, \& J. Kilpatrick (Eds.), Posing and Solving Mathematical Problems (pp. 109-113). Switzerland: Springer. https://doi.org/10.1007/978-3-319-28023-3_7

Mills, G. E., \& Gay, L. R. (2016). Educational Research: Competencies for Analysis and Applications (11 ${ }^{\text {th }}$. ed.). Boston: Pearson Education.

Ministry of Education Malaysia. (2013). Malaysia Education Blueprint 2013-2025 (Preschool to Post-Secondary Education). Education. Putrajaya: Ministry of Education Malaysia.

Ministry of Education Malaysia. (2016). Malaysian Education Blueprint (2013-2015) Annual Report 2015. Putrajaya: Ministry of Education Malaysia.

NCTM. (2010). Why is teaching with problem solving necessary to student learning? National Council of Teachers of Mathematics, 13(12), 1-6. https://doi.org/10.1016/S2213-8587(14)70016-6

Ong, H. C., \& Lim, J. S. (2014). Identifying factors influencing mathematical problem solving among matriculation students in Penang. Pertanika Journal of Social Science and Humanities, 22(1), 393-408.

O'Neil, H. F., \& Abedi, J. (1996). Reliability and Validity of A State Metacognitive Inventory: Potential for Alternative Assessment. Journal of Educational Research, 89(4), 234-245. https:// doi.org/10.1080/00220671.1996.9941208

Özcan, Z. Ç., \& Gümüş, A. E. (2019). A modeling study to explain mathematical problemsolving performance through metacognition, self-efficacy, motivation, and anxiety. Australian Journal of Education, 63(1), 116-134. https:// doi.org/10.1177/0004944119840073

Öztürk, M., Akkan, Y., \& Kaplan, A. (2020). Reading comprehension, Mathematics selfefficacy perception, and Mathematics attitude as correlates of students' nonroutine Mathematics problem-solving skills in Turkey. International Journal of Mathematical Education in Science and Technology,51(7), 1042-1058. https://doi.org/10.1080/0020739X.2019.1648893 
Pallant, J. (2020). SPSS survival manual: A step-by-step guide to data analysis using IBM SPSS. Routledge.

Peteros, E., Columna, D., Etcuban, J. O., Almerino, Jr., P., \& Almerino, J. G. (2019). Attitude and Academic Achievement of High School Students in Mathematics Under the Conditional Cash Transfer Program. International Electronic Journal of Mathematics Education, 14(3), 583-597. https://doi.org/10.29333/iejme/5770

Polya, G. (1957). How to solve it: A new aspect of mathematical method (2nd. ed.). Princeton, NJ: Princeton University Press.

Prendergast, M., Breen, C., Bray, A., Faulkner, F., Carroll, B., Quinn, D., \& Carr, M. (2018). Investigating secondary students beliefs about mathematical problemsolving. International Journal of Mathematical Education in Science and Technology, 49(8), 1203-1218. https://doi.org/10.1080/0020739X.2018.1440325

Rincon, G. A., Cézar, R. F., \& Hernandez, C. F. (2020, March). Beliefs about mathematics and academic performance: A descriptive-correlational analysis. In Journal of Physics: Conference Series (Vol. 1514, No. 1, p. 012021). IOP Publishing. https:// doi.org/10.1088/1742-6596/1514/1/012021

Salkind, N. J. (2012). Exploring Research (8 ${ }^{\text {th }}$. ed.). New Jersey: Pearson Education, Inc.

Salim, N. R., Gopal, K., \& Ayub, A. F. M. (2018, June). The influence of statistics selfefficacy towards statistics engagement among undergraduate students. In AIP Conference Proceedings (Vol. 1974, No. 1, p. 050005). AIP Publishing LLC. https://doi.org/10.1063/1.5041705

Simegn, E. M., \& Asfaw, Z. G. (2018). Assessing the Influence of Attitude Towards Mathematics on Achievement of Grade 10 and 12 Female Students in Comparison with Their Male Counterparts: Wolkite, Ethiopia. International Journal of Secondary Education, 5(5), 56. https://doi.org/10.11648/j.ijsedu.20170505.11

Stylianides, A. J., \& Stylianides, G. J. (2014). Impacting positively on students' mathematical problem solving beliefs: An instructional intervention of short duration. Journal of Mathematical Behavior, 33(1), 8-29. https:// doi.org/10.1016/j.jmathb.2013.08.005

Tambunan, H. (2019). The Effectiveness of the Problem Solving Strategy and the Scientific Approach to Students' Mathematical Capabilities in High Order Thinking Skills. International Electronic Journal of Mathematics Education, 14(2), 293-302. https://doi.org/10.29333/iejme/5715

Tarmizi, R. A., Kargar, M., \& Saadati, F. (2015). Correlates of Mathematics Attitude and Problem Solving Behaviour among Teheran, Republic of Iran Year 10 Students. Jurnal Pendidikan Sains Dan Matematik Malaysia, 5(1), 18-34.

Tapia, M., \& Marsh, G. E. I. (2004). An Instrument to Measure Mathematics Attitudes. Academic Exchange Quarterly, 8(2), 16-21.

Usher, E. L., \& Pajares, F. (2009). Sources of Self-efficacy in Mathematics: A validation study. Contemporary Educational Psychology, 34(1), 89-101.

Veenman, M. V., \& van Cleef, D. (2019). Measuring Metacognitive Skills for Mathematics: Students' Self-reports Versus Online Assessment Methods. ZDM, 51(4), 691-701. https:// doi.org/10.1007/s11858-018-1006-5

Wang, G., Zhang, S., \& Cai, J. (2019). Chinese High School Students' Mathematics-Related Beliefs and Their Perceived Mathematics Achievement: A Focus on Teachers' Praise. EURASIA Journal of Mathematics, Science and Technology Education, 15(7), 112. https://doi.org/10.29333/ejmste/105875

Warner, S., \& Kaur, A. (2017). The perceptions of teachers and students on a 21st Century mathematics instructional model. International Electronic Journal of Mathematics Education, 12(2), 193-215. 